\title{
TRAUMA, DOR E ATO: O OLHAR DA PSICANÁLISE SOBRE UMA TENTATIVA DE SUICÍDIO
}

\author{
Mônica Medeiros Kother Macedo \\ Blanca Susana Guevara Werlang
}

Mônica Medeiros Kother
Macedo
Psicóloga,
psicanalista,
doutora em
Psicologia (PUCRS),
professora adjunta
e coordenadora
do Serviço de
Atendimento
e Pesquisa em
Psicologia da
Faculdade de
Psicologia da
PUCRS e Membro
Pleno da Sociedad
Psicoanalítica del
Sur de Buenos Aires.
Blanca Susana Guevara
Werlang
Psicóloga, doutora
em Ciências
Médicas/Saúde
Mental (Unicamp),
professora
adjunta e diretora
da Faculdade
Psicologia da
PUCRS, membro do
Grupo de Trabalho
para implantar a
Estratégia Nacional
de Prevenção ao
Suicídio (Ministério
da Saúde).
PUion

RESUMO: As relações existentes entre trauma, dor psíquica e ato são abordadas por meio da análise do caso clínico de uma pessoa que efetivou uma tentativa de suicídio. Explora-se a inter-relação entre o traumático, a ruptura das barreiras de proteção ao psiquismo e o predomínio do irrepresentável que tem como conseqüência o ato de tentar tirar a própria vida. A partir da metapsicologia psicanalítica, nomeia-se a tentativa de suicídio como um ato-dor.

Palavras-chave: Trauma, dor psíquica, tentativa de suicídio, atodor, metapsicologia psicanalítica.

ABSTRACT: Trauma, pain and act: a Psychoanalytic look on the attempt of suicide. The existing relations among trauma, psychic pain and act are approached by means of the analysis of the clinical case of a person that has performed a suicide attempt. The interrelation among the traumatic, the breaking of the psyche protection barriers and the prevalence of the "unrepresentative" contents predominance that as a consequence produces the act of trying to take one's own life. Through psychoanalytic metapsychology a suicide attempt is named as a pain-act.

Keywords: Trauma, psychic pain, attempt of suicide, pain act, psychoanalytic metapsychology.

A psicanálise nasce a partir da investigação de Freud a res-
em compreender o que o sintoma manifestava e, ao mesmo
tempo, escondia, motiva Freud a embrenhar-se numa inves-
tigação por caminhos tortuosos e difíceis. Para criar e manter
a vitalidade da psicanálise, ele precisará, ao longo do tempo,
defender com coragem e determinação conceitos fundamentais
como inconsciente, sexualidade, recalcamento e transferên- 
cia. Sem dúvida, ao longo de sua obra, o pilar central é sua crença na etiologia inconsciente e sexual dos padecimentos psíquicos.

$\mathrm{Na}$ busca por melhores recursos técnicos a serem utilizados na condução de um processo de cura, Freud (1895/1987) atende ao inusitado pedido da paciente Emmy Von N.: ela deseja que ele a escute em silêncio. E assim, exercitando a capacidade de escuta, Freud irá descentrando o analista do lugar de poder para o qual a hipnose acenava. Busca, a partir de então, cada vez mais, a participação de um sujeito acordado e ativo no processo de conhecimento de seu inconsciente. Assim, ao dar à transferência um lugar de destaque no cenário da clínica, Freud redimensiona o papel do analista, abrindo um espaço único de escuta às repetições singulares de uma história. Revisitando via auto-análise sua história infantil, os recônditos mais íntimos de seu ser, Freud torna-se um guia ainda mais habilitado para acompanhar a viagem analítica de seus pacientes. Dessa maneira, os conceitos da psicanálise e sua metapsicologia servirão como instrumentos de investigação e acesso à peculiar natureza humana.

A psicanálise, como teoria e técnica, propõe um olhar livre de "pré-conceitos" para as dores da alma. Freud (1905/1972), ao referir-se às doenças de etiologia psíquica, afirma que "os leigos, que gostam de rotular influências mentais desta espécie como 'imaginação', inclinam-se a demonstrar pouco respeito por dores devidas à imaginação em contraste com as causadas por ferimentos, doença ou inflamação". Acrescenta, ainda, que isto é claramente injusto, pois considera que, mesmo que as dores sejam causadas pela imaginação, "elas próprias não são menos reais nem menos violentas por isto" (p.320).

Fiel a esse posicionamento a respeito dos padecimentos psíquicos, já nos textos de 1892 e 1895, um tema ocupa Freud: o trauma. Marca-se, nesse tempo inicial, uma estreita relação entre trauma, realidade e histeria. Entretanto, à medida que Freud aprofunda seus estudos, a concepção de trauma sofre importantes transformações. Assim, as afirmativas dele a respeito do trauma permitem encontrar, independentemente da clínica com o paciente histérico, uma verdadeira vitalidade do conceito, resultando no que pode se chamar uma teoria do trauma.

Freud (1892/1987) afirma que "transforma-se em trauma psíquico toda impressão que o sistema nervoso tem dificuldade em abolir por meio de pensamento associativo ou da reação motora" (p.174). Esse momento teórico freudiano permite que se faça uma leitura antecipada, mas legitimada por seus avanços posteriores, de que o aparelho psíquico trabalha para manter constante, em seu interior, a "soma de excitação", e alcança tal condição na medida que tramita todo o considerável aumento de excitação por via associativa ou via descarga mediante uma reação motora correspondente.

A carta de 21 de setembro de 1897, escrita a Fliess, explicita o abandono da teoria do trauma, abrindo um espaço fundamental para o conceito de fantasia. 
Considera-se que o abandono da idéia de uma cena real de sedução para explicar a etiologia da histeria não pode resultar em uma leitura apressada da exclusão de uma teoria do trauma na psicopatologia psicanalítica. Além do abandono de uma idéia de sedução real, Freud renuncia à linearidade da compreensão de uma patologia. O efeito traumático nas produções psíquicas evidencia a impossibilidade da manutenção do trauma unicamente vinculado à histeria. Num movimento de abandono, mais do que nunca, se abrem portas para pensar a significação psíquica (interna) dos efeitos de um trauma, seja real ou imaginário.

No ano de 1920, Freud escreve "Além do princípio do prazer". Este texto nasce de sua experiência com os horrores da guerra e possibilita a descoberta de que a repetição não se dá apenas nos caminhos do prazer. Apresenta seu conceito de compulsão à repetição e também resgata algumas concepções sobre o ingresso de quantidades no aparelho psíquico, temática que já de alguma forma abordara no "Projeto para uma psicologia científica", em 1895.

A noção de excesso está intimamente vinculada, em 1920, à noção de quantidades que invadem o psiquismo, rompendo a proteção das pára-excitações. Observa-se que Freud avança em relação ao que já anunciara em 1895 sobre a diferença entre descarga e fuga. Cabe à fuga um recurso no que se refere aos estímulos externos, já que em relação ao que ingressa no psiquismo a dinâmica é outra. A intolerância do aparelho frente ao que o invade gera uma tendência a desprender-se dessa situação por caminhos conhecidos, os quais foram eficazes em situações anteriores. No texto de 1920, Freud utiliza a metáfora de um território invadido para explicar o que se passa no aparelho psíquico quando, frente à vivência de um excesso, são rompidas as barreiras pára-excitações. Pode-se identificar aí a retomada de suas concepções sobre a teoria do trauma. Agora, Freud nomeia o traumático não apenas no terreno da neurose, pois amplia sua proposição a respeito do dualismo pulsional que habita o homem. Na reprodução do circuito pulsional, observa-se a força demoníaca da pulsão de morte; a repetição se dá a partir do que nunca foi registro de prazer para o aparelho psíquico.

Considera-se ser a força destrutiva de Tânatos o motor que impulsiona as diversas manifestações do comportamento suicida. Assim, este artigo tem como objetivo apresentar, por meio de uma ilustração clínica, as relações existentes entre trauma, dor psíquica e ato, considerando-se a ocorrência de uma situação de tentativa de suicídio. Não se pretende afirmar ou defender uma espécie de equação que "explique" as tentativas de suicídio de modo geral. Ao contrário, fiel aos ensinamentos da psicanálise, dedica-se especial cuidado e atenção à singularidade sempre presente no sofrimento humano. Pretende-se, desse modo, desenvolver um raciocínio teórico, com aplicabilidade clínica, o qual demonstra serem algumas situações de tentativas de suicídio resultantes de contextos nos quais o sujeito se vê acometido por um excesso (trauma) que seu aparelho 
psíquico mostra-se incapaz de processar e metabolizar. O material clínico apresentado ilustra situações que viabilizam pensar a tentativa de suicídio como um ato resultante da vivência e da experimentação de intensa dor psíquica. Nessa situação, o ato de matar-se parece ser a única via de descarga possível.

Entende-se, portanto, que, frente a essa tentativa de suicídio, a pessoa encontra-se no terreno da psicopatologia. A palavra patologia deriva do grego pathos, que significa sofrimento, e da qual também se derivam as palavras paixão e passividade (BERLINCK, 2000). A inter-relação entre estes três sentidos da palavra pathos parece destacar-se na situação de uma tentativa de suicídio que se pretende ilustrar. Ao considerar-se a tentativa de suicídio como um ato decorrente da força do traumático que resulta na incapacidade de dar figurabilidade à dor psíquica, destaca-se a dinâmica singular de um ato. Busca-se compreender a relação entre sofrimento, paixão (excesso) e passividade, considerando o tema do trauma e seus efeitos no psiquismo. Propõe-se, então, como tema central deste artigo, a compreensão desta situação na qual, frente à ação do traumático, a ausência de palavras, provocada pela força do irrepresentável, leva o indivíduo a um ato de tentar dar fim à própria vida. O prefixo psico, acrescido da palavra patologia, alude a essa dimensão de excesso relacionada ao que é para o aparelho psíquico de difícil ou impossível elaboração.

Conforme Berlinck (2000), quando pathos acontece, "algo da ordem do excesso, da desmesura se põe em marcha sem que o eu possa se assenhorear desse acontecimento, a não ser como paciente, como ator" (p.18). A desmesura de pathos alude a algo que excede, que vai além do possível de ser suportado. Assim, entende-se ser pertinente propor uma articulação entre a noção de patologia e uma situação de invasão de intensidades decorrentes do traumático no território psíquico. Entende-se ser a "patologia” um processo que envolve sempre a noção de temporalidade, na medida que alude ao ocorrido antes, remete à sucessão de fatos e a acontecimentos importantes na vida da pessoa. A partir desses fatos, dessa linha de temporalidade, ocorrem as diferentes formas de processamento das possíveis situações de conflito psíquico (FISCHBEIN, 1999).

Diferente de uma proposta de cura da medicina que visa restabelecer um estado anterior, ou seja, visa retornar a um estado antes saudável, na cura psicanalítica, se são colocados objetivos terapêuticos, esses apontam, segundo Hornstein (1989), “a algo que antes não existia, a não ser em forma potencial: o projeto terapêutico tem a ver, de fato, com o desenvolvimento de potencialidades que as inibições, sintomas e estereótipos caracteriais do paciente haviam diminuído" (p.40). Acredita-se, que em algumas situações de tentativas de suicídio, considerando-se a escuta analítica, trata-se exatamente do que menciona o autor. A escuta do ato da tentativa de suicídio pode ajudar o sujeito a criar e/ou desenvolver sua potencialidade simbólica. Portanto, parte-se do pressu- 
posto de que o que é descarregado no ato de tentar acabar com a própria vida tem íntima relação com um excesso derivado de vivências traumáticas às quais não foi possível dar uma atribuição de sentido ou obter uma captura no mundo representacional do sujeito.

O caso de tentativa de suicídio abordado neste artigo circunscreve-se a um modelo no qual a vivência traumática imprime-se como uma marca a ferro e fogo que impõe uma repetição cega. O que se repete é a intensidade não qualificada ou simbolizada. Assim, a tentativa de suicídio, como saída, põe em evidência um ato que precisa ser escutado e historizado. Ao buscar a própria morte, o sujeito convoca o analista a uma escuta do que está além do desejo recalcado da neurose. Trata-se de uma escuta da urgência, pois se sabe da possibilidade de que, frente a um fracasso de uma tentativa, outra poderá vir a ocorrer. O ato suicida explicita um fracasso no processamento psíquico de intensas cargas afetivas (KNOBLOCH, 1998; FISCHBEIN, 1999; GEREZ-AMBERTIN, 2003). A tentativa de suicídio pode resultar em uma situação sem ponto de retorno. Werlang e Botega (2004) alertam sobre o fato de que 20 a 50\% das pessoas, que acabam se matando, já haviam tentado o suicídio antes. Portanto, segundo os autores, a existência de uma tentativa de suicídio mostra a probabilidade de que um suicídio venha realmente a ocorrer.

O eixo teórico da proposição, de ser a tentativa de suicídio um ato-dor, pode ser inferido do texto de 1920 de Freud, no qual o conceito de trauma é recuperado a partir de uma perspectiva do violento, do intrusivo, que gera uma demanda significativa de processamento psíquico. Mais do que colocar em pauta uma discussão entre trauma real e fantasia, evidencia-se a partir disso, a necessidade de pensar, a partir da perspectiva do sujeito, no efeito do excesso que o invade. Nesta linha de pensamento, alinha-se este artigo. Trata-se de propor a inter-relação existente entre vivências de excesso, portanto, traumáticas, dor psíquica e ato. Devido à impossibilidade de um processo de simbolização dessas quantidades, o traumático não encontra meios de metabolização psíquica. A operação que falha é a da simbolização.

No presente trabalho, parte-se de considerações a respeito da magnitude do traumático conforme proposto por Freud (1920/1976) em seu texto de 1920: “um acontecimento como um trauma externo está destinado a provocar um distúrbio em grande escala no funcionamento da energia no organismo e a colocar em movimento todas as medidas defensivas possíveis" (p.45). Portanto, propõe-se ser a tentativa de suicídio, naquelas situações nas quais se encontra na história de vida do sujeito um contexto de predomínio do traumático, uma forma de dar vazão a esse excesso via ato de tentar tirar a própria vida. Apresenta-se uma ilustração clínica a partir da qual se pretende trabalhar a inter-relação existente entre trauma, dor psíquica e ato, assim como apresentar o conceito de ato-dor. 


\section{MORFINA E DOR PSÍQUICA}

O caso a ser apresentado integrou uma investigação mais ampla a respeito da história de vida de tentadores de suicídio e sua motivação para cometer tal ato. O material clínico que será, aqui, parcialmente exposto derivou-se de um conjunto de entrevistas realizadas com Gerusa por ocasião de sua internação hospitalar por tentativa de suicídio.

Gerusa tem 25 anos e é a primeira filha de seus pais. Está prestes a concluir o curso superior na área das ciências humanas. Sua infância foi tumultuada devido ao alcoolismo paterno e a violentas brigas no núcleo familiar. Os relacionamentos familiares giravam em torno de brigas por ciúmes, desconfiança e ameaças de morte. Seus relacionamentos amorosos sempre foram às escondidas, tendo rompido há pouco tempo um namoro de quatro anos, aparentemente sem maiores dificuldades. Sua primeira tentativa de suicídio foi por ingestão de medicamentos, sendo a segunda, a mais grave, por ingestão de morfina.

O traumático adentra sua história desde a infância. Quando tinha cerca de dois anos e meio, nasceu seu irmão. Sobre este fato conta:

"Lembro quando meu irmão nasceu. Rasguei todo o meu vestido. O pai e a mãe foram embora e eu fiquei ali, ninguém me explicou nada, não sabia onde estava o nenê, nada. Eu rasguei todo o vestido, me lembro bem da cena. A mãe conta que naquela semana eu fiquei bem sensível, queria chamar a atenção e o meu pai me bateu. Eu tinha uns ataques assim, quando eu ficava braba, eu batia a cabeça no chão, esperneava. Não chegava a me machucar. Só batia a cabeça no chão, gritava. Aos poucos ia me acalmando. Mas meu pai perdeu a paciência e me deu uma surra, que era para nunca mais eu fazer aquilo. A mãe conta que eu nunca fiz mais, aí comecei a ter asma."

Na dinâmica dos fatos relatados, Gerusa anuncia o destino que terá o que não puder ser processado psiquicamente. Se não pode representar via palavras o que a ataca intrapsiquicamente frente ao nascimento do irmão, passa a manifestar nas crises de asma o que lhe é de indescritível sentido. A crise de asma está associada no contexto médico a uma impossibilidade de expirar. Ou seja, o paciente com asma retém o que inspira, não conseguindo transformar oxigênio em gás carbônico $\left(\mathrm{CO}_{2}\right)$. Fazendo uma analogia, Gerusa, na impossibilidade de desfazer-se do que a atacava por dentro, o efeito do traumático, mutila-se psiquicamente. Ela não consegue encontrar recursos nas palavras. Fica sem poder "trocar" com o ambiente que a circunda e "transforma" dor em asma. Frente à desautorização paterna, fica invadida por um excesso e submetida fisicamente a uma doença. Nesse sentido, o termo pathos mostra a desmesura que se "nomeia" em ato e não em palavra. O excesso é um companheiro no dia-a-dia de Gerusa: 
“Meu pai era alcoolista e um homem muito violento. Ele não batia, mas dizia coisas que magoavam $e$ machucavam muito. Era muito castrador, eu não podia fazer nada, ter amigos, sair, ter namorados. Ele não deixava, ficava com ciúmes. Era bem difícil, tinha um gênio violento. Quando bebia, ficava pior, mas mesmo sem beber não era fácil."

O início de sua adolescência provocou, segundo a própria Gerusa, uma importante mudança no vínculo já frágil com seu pai. O pai se afastou física e afetivamente dela, passando a controlar suas saídas e amizades. Gerusa sentia-se muito triste por não poder sair e fazer as coisas de que gostava. Sua rotina se restringia a ir da casa para o colégio e do colégio para casa. Acabava obedecendo ao pai por medo de seu gênio violento, independentemente da bebida.

"Era difícil porque muitas vezes eu queria ir e não achava justo ele me proibir... eu não poder fazer as minhas coisas. Mas aí se criava todo um problema dentro de casa. Por outro lado, eu me sentia meio que culpada de estar criando briga dentro de casa com a minha mãe, com o meu irmão sendo que, muitas vezes, eu acabava fazendo escondido."

Seu temor era comprovado na realidade com o comportamento paterno. Não se tratava de fantasias em relação a um pai ciumento, mas sim de experimentar fatos reais de violência.

"Uma vez eu briguei com ele porque cheguei um pouco mais tarde em casa, e ele tinha uma arma, estava no meio da sala com a arma.[...] Uma vez a gente brigou e ele veio para cima de mim, me bateu e eu tive uma luxação no dedo. Meu irmão veio me defender, ele pegou a arma e ameaçou meu irmão. Se a gente deixasse, a coisa chegava ao extremo. [...] Se a gente desafiasse ele, ele pegava a arma. Então eu ficava quieta."

A relação com a mãe, segundo Gerusa, era melhor. Porém, após uma marcante situação de violência do pai para com a esposa e frente à recusa desta em manter-se separada dele, Gerusa passa a ter também dificuldades no relacionamento com a mãe. Expressa, claramente, não entender a manutenção do casamento por parte dela. Percebe-se nesse momento a desestabilização de um vínculo de confiança e apoio entre ambas. A violência do pai, que tinha, segundo Gerusa, a mãe como alvo principal no que diz respeito não apenas a ameaças de morte, mas também a desconfianças de traição, evidencia não se tratar de um ciúme neurótico. Pelo caráter quase persecutório e delirante das fantasias paternas de traição, assim como pela violência desmedida, insinuam-se possíveis fantasias e desejos homossexuais deste homem. Freud (1922/1976) menciona o caso de um paciente que sentia intensos ciúmes da esposa. Descreve o modo como esse homem vigiava "a mente inconsciente de sua esposa" (p.274), interpretando seus 
atos mais casuais como confirmações de traição. Freud (1922/1976), ao traçar um paralelo entre a ambivalência da paranóia e o ciúme excessivo, considera que a "ambivalência serve, assim, para o paranóico, ao mesmo objetivo que o ciúme servia ao meu paciente: o de uma defesa contra o homossexualismo" (p.275). Seria essa uma hipótese também viável no caso do pai de Gerusa, pela freqüência e característica de repetição nas cenas de intensos ciúmes que tinha na relação com a esposa e com a filha.

Sobre o irmão, Gerusa conta que, há pouco tempo, obteve dele mesmo a confirmação das suspeitas a respeito de sua homossexualidade. Menciona que seus pais sempre fizeram de conta que não sabiam o que se passava com o irmão:

"A gente sempre se deu bem. Passamos por muitas coisas juntos e como somos irmãos é diferente. A mãe viveu também, mas é mãe. Ele é gay, mas minha mãe não sabe. Melhor, ela não quer saber. Não é que ele esconda, só não vê quem não quer. Todo mundo no trabalho dele sabe. Os amigos dele vão lá em casa; ele tem amigos bem afeminados. Ela não aceita de jeito nenhum. Ele vai à parada gay e mostra as fotos. É tapar 0 sol com a peneira. Ela me dá umas indiretas, pergunta que tipo de figura materna ele teria, mas o que ela quer é que eu confirme que ele não é gay. Eu não falo nada. O pai também não sabia, não sabia como a mãe não quer saber. Quando ia alguma amiga dele lá em casa, eles ficavam felizes e aliviados."

Apesar da boa relação que demonstra ter com o irmão, percebe-se no relato de Gerusa que ambos acabam se encontrando pouco, sendo que André tem atualmente uma vida ainda mais distanciada de Gerusa e da mãe. Na medida que ela conta fatos de sua infância e de sua adolescência, fica evidente o quanto ela e seu irmão se aproximavam pelo temor de que algo de terrível acontecesse devido ao caráter violento do pai.

Com 15 anos, Gerusa faz sua primeira tentativa de suicídio. Ingere grande quantidade de remédios, mas, assustada com a forte taquicardia, acaba pedindo ajuda à mãe e ao irmão, sendo levada à emergência de um hospital. Lembra:

\footnotetext{
"Minha mãe ficou bem nervosa, meu pai estava tão alcoolizado que nem viu nada, ficou dormindo. Eu não tinha vontade própria $[\ldots]$, o meu pai continuava daquele jeito, não podia ir à casa das minhas amigas, não tinha ninguém para conversar. Fim de semana não podia, pois tinha que ficar estudando $e$ fazendo os trabalhos. Os 14 e os 15 anos foram bem difíceis [...] Mas aí eu pensei em ir ao psiquiatra, toda vez que ele via que eu ia ao psiquiatra, me dizia que eu era louca."
}

Ser nomeada como louca deixa Gerusa ainda mais sem possibilidade de enxergar um caminho de esperança. Buscar ajuda é adquirir a condição de louca. Com outra ilustração, conta o modo como "resolvia” e explicitava sua indignação ou raiva. Por não querer debutar conforme desejo paterno, ela corta 
todo seu longo cabelo. Acaba por debutar de cabelo curto com uma imagem despersonalizada da feminilidade cujo exercício se dá sempre às escondidas ou no território da dor. Precisa fazer um esforço frente às poucas amigas que vão até sua casa para que não percebam o ambiente familiar. Nessas ocasiões, o pai mostrava-se amável na frente dos outros, mas, se algo o desagradasse quando estavam a sós, as ameaças voltavam.

Ao abordar o aspecto imperativo de silenciar sobre o traumático, Maia (2003) considera que a solidão do silêncio faz com que o ocorrido não possa ser inscrito num registro de significações a fim de ocupar um espaço de passado para chegar a um posterior esquecimento. Portanto, essa espécie de "buraco negro", nomeado pela autora, passa a funcionar com uma força de atração. Por isso, no terreno do traumático, não se está descrevendo um processo de recalcamento, mas, sim, de clivagem.

Ao trabalhar as proposições de Freud a respeito da cisão do eu (Ichspaltung) e da defesa denominada por Freud de desmentido (Verleugnung), Figueiredo (2003) traz uma importante contribuição. O autor propõe que Verleugnung seja nomeada como desautorização. A desautorização, segundo Figueiredo, nega a autorização para que um episódio de ruptura se inscreva no campo da experiência do sujeito e que este sujeito se converta em autor desta experiência. No processo de desautorização, “o que se recusa não é uma dada percepção, mas o que vem ou viria depois dela, seja como uma percepção que a primeira torna possível, uma possibilidade de simbolização, uma conclusão lógica aparentemente necessária ou uma lembrança que a percepção pode ativar”. Trata-se, então, de impedir, via desautorização, "que o que se vê leve o psiquismo ao que poderia inferir daquilo que foi visto” (p.60).

Para Ferenczi (1933a/1992) é, exatamente, a impossibilidade de representar o ocorrido que torna o traumático patogênico. Ao mesmo tempo que busca proteger-se dessa maneira, o sujeito denuncia sua fragilidade psíquica. A vivência traumática fica excluída de um contexto significativo. Segundo Fischbein (1999), "a tendência à descarga e ao ato são os elementos básicos que observamos naqueles estados nos quais o sujeito repudia a dor de reconhecer seus limites e carências. São estados de repúdio das representações que dão figurabilidade à dor psíquica” (p.266).

Na história de Gerusa, esse aspecto está presente em seus relatos sobre a morte de pessoas da família:

“Fiquei pensando sobre essa coisa que eu tenho com o meu pai. Ele já faleceu e eu não consigo sentir, sabe?

E com a morte da minha vó, a mesma coisa aconteceu. [...] Mas eu achava que era por eu não conviver com ela todo o dia. [...] E com meu tio também foi a mesma coisa. E eu fui no enterro dos dois. A vó, inclusive, cheguei a ver quando ela estava mal na UTI. Vi ela morta, depois quando arrumaram ela, 
quando vestiram ela, prepararam ela. Eu não estava junto, mas eu vi. [...] Eu chorei, mas parecia que era uma coisa natural, sabe? E a vó morreu assim, ninguém esperava que ela fosse falecer.”

Em 1997, o pai de Gerusa tem o diagnóstico de câncer na laringe. Faz o tratamento aparentemente com certo sucesso, mas surge um novo câncer no pulmão em janeiro de 2004. O estado de saúde dele piora consideravelmente até ser desenganado pelos médicos. Gerusa envolve-se muito nos cuidados com o pai, sendo que reveza suas atividades de estágio da faculdade com períodos no hospital, cuidando dele após um longo tratamento em casa. Nesta mesma época, rompe um namoro de quatro anos. Sente-se pouco apoiada pelo namorado na situação de morte iminente do pai. Este rompimento não foi, aparentemente, difícil para ela, pois relata que há tempos se sentia distante dele. Percebia-o muito ocupado com suas próprias coisas e sentia-se pouco considerada por ele. Porém, desde janeiro de 2005, por sentir-se cansada e muito desanimada, Gerusa busca, de novo, ajuda psiquiátrica.

Em agosto de 2005, na fase terminal da doença paterna, Gerusa, no hospital, tem uma discussão com a mãe que desencadeia sua segunda tentativa de suicídio.

\footnotetext{
"Foi muito uma solução; eu estava muito cansada, muito estressada. O estopim foi quando que eu briguei com a mãe no hospital. Nós brigamos por causa de um creme. Eu comentei que tinha um creme que estava em promoção e que a minha tia estava vendendo no hospital. Daí, ela me chamou de consumista, que eu estava num hospital, que tudo era baratinho para mim, começou a me dizer um monte de coisas. [...] Ela dizia que a minha faculdade já era cara, que ela não sabia como a gente ia ficar de pensão depois que o meu pai falecesse. E eu me senti assim um cheque, dinheiro... tudo que eu fazia parecia que não tinha valor nenhum. Eu me senti um nada. Eu saí do hospital e, quando cheguei em casa, tudo que ela falou estava na minha cabeça. Lembro que tentei ligar para o meu terapeuta, mas não consegui falar com ele. [...] Estava precisando falar com alguém, mas sabia que ninguém ia estar em casa; daí fui para a cozinha e vi os vidros de morfina que eram do pai. [...] Eu tomei tudo que tinha: eram seis vidros. Depois que tomei, deitei e apaguei, rapidinho. Só lembro de umas vozes no hospital me chamando. Perdi totalmente a noção."
}

A tentativa de suicídio de Gerusa é considerada muito grave pelos médicos. Fica dez dias na UTI, correndo risco de vida por sérios problemas respiratórios e uma parada cardiovascular. Precisa de ventilação mecânica e cuidados especiais. Sai da UTI, mas seu estado de saúde exige a permanência de mais 30 dias de hospitalização. Seu pai vem a falecer exatamente no período de sua internação. Conta que, quando pequena, rezava para o pai morrer, pois achava que essa era a única forma de terem paz dentro de casa. O pai estava aposentado desde que ela tinha 10 anos e ficava durante o dia em casa com os filhos, alcoolizado, enquanto a esposa trabalhava. 
"A gente tinha muita raiva, por causa da situação toda que estava acontecendo. Muitas vezes a gente pensava, queria que ele morresse mesmo. Lembro que não queria que ele parasse de beber porque eu pensava que por um lado até era bom, pois assim ele morre mais cedo. A gente sempre tinha a impressão que era só ele morrendo, porque a mãe tentou se separar uma vez e, se ela se separasse dele, ele ia matar ela, e ia acabar acontecendo algumas outras coisas que ela tinha medo. Então parecia que essa era a única solução. Que ele morresse mesmo, era isso que a gente comentava dele. E, quando ele parava de beber, parecia ser pior, porque ele ficava insuportável."

Como Gerusa não acompanha a morte do pai, sente-se confusa em relação ao ocorrido.

"Está tudo bem misturado. É estranho porque, quando eu estava no hospital, ele morreu. Eu não consigo sentir que ele morreu, é esquisito. [...] Não acompanhei quando ele morreu, então é estranho, não consigo sentir. Até converso com mãe, mas é meio estranho. [...] Quando eu soube o que tinha acontecido, a primeira coisa que eu senti foi um alívio. Eu sabia que ele não estava sofrendo mais, ele já estava um corpinho, pequeno. Ao mesmo tempo me dá um alívio, alivio porque, tipo isso foi muito marcante na minha personalidade, sabe?"

A clivagem protege Gerusa de uma invasão de sentimentos, mas deixa-a no terreno da dor. O conceito de clivagem, aqui, é utilizado no sentido que lhe atribui Maia (2003). Para a autora, a clivagem está relacionada nos textos de Freud a um movimento de recusa. Essa recusa "abre a possibilidade de que possam coexistir no ego duas atitudes psíquicas diferentes frente à realidade: a primeira leva a realidade em consideração; a segunda, atendo-se à sobrevivência psíquica, nega-a" (MAIA, 2003, p.166). Para proteger-se da dor, Gerusa acaba abrindo mão de parte de si mesma. Não pode sentir quando na verdade está atordoada pela dor que provoca esse excesso não representado simbolicamente. A dor não consegue ser processada como sentimento. Segundo Fischbein (1999), a bagagem representacional do sujeito protege-o do impacto de estímulos. No caso de Gerusa, falta-lhe esse recurso. A clivagem aparece como única possibilidade de "defesa". Para Maia (2003), na clivagem, "coloca-se em xeque a integridade narcísica, na medida que aquilo que é silenciado exige a redefinição do sujeito, endurecendo suas vias de afetação para com o mundo: o eu terá que vigiar este que dentro dele é vivo e morto simultaneamente" (p.155).

No texto "Projeto para uma psicologia científica, Freud" (1895/1987) utiliza a concepção de invasão de quantidades no aparelho psíquico, as quais, de tão intensas, chegam até mesmo a fazer desaparecer a possibilidade de investimento em um mundo representacional. Nesta situação, frente a quantidades intensas e inesperadas, a capacidade de retenção de memória é substituída por uma condição de passagem equivalente a uma ausência de memória. Assim, nesse contexto, 
Freud (1895/1987) aborda a questão da dor psíquica. A dor está intimamente ligada a um acréscimo de quantidades no aparelho psíquico. A dor deixa uma marca, um rastro, efeito desse excesso. A condição representacional está abalada nessa situação. Valls (2004) escreve que "Freud está explicando aqui como o trauma vai gerando no aparato psíquico espaços sem investimento de representação de um objeto". Acrescenta ainda o autor que, por mais que, em segunda instância, tente-se buscar essa representação, mesmo que ainda se consiga isso, “me parece que serão investidas, em todo caso, representações que se prestam aos fins de repetir a sensação dolorosa e seguramente o que mais se repetirá nelas não será somente determinada cena senão o fato de que qualquer cena da vida possa terminar em dor". Ou seja, tais cenas, segundo o autor, "buscam simplesmente repetir a dor, o trauma” (p.82). Portanto, nesta leitura, encontram-se subsídios para se pensar que o efeito do resto da dor leva a uma busca de repetição, ou melhor, tem como efeito a instalação de um circuito de repetição da dor. Mesmo quando alcança algum tipo de representação, esta visa reproduzir a dor, o trauma. Uma dor primeira (excesso) gera repetições, que são "tentativas de criar uma representação" do irrepresentável, mas que, diante da impossibilidade disto, cedem espaço ao ato como única alternativa de descarga.

As vivências de maus-tratos e violência deixam à Gerusa um modelo de dor que fica se repetindo num circuito no qual ora é ativa, ora é passiva. Corta seus cabelos (ato dirigido contra si mesma) no "protesto" contra todos os cortes que recebe do pai, tentando desviar a hostilidade que teria a figura paterna como alvo. Antes, frente ao nascimento do irmão, a ira se transforma em asma. Batia com a cabeça no chão, machucava-se fisicamente frente a uma dor da alma. O que se passava com Gerusa por ocasião do nascimento do irmão não pode ser nomeado como uma situação de ciúmes. Talvez, frente à pobreza dos vínculos com as figuras parentais, a chegada de um irmão ameaçasse deixá-la ainda com menos do pouco que recebia.

Nesta seqüência de contar fatos de sua história, descreve uma cena entre o pai e a mãe que a marcou profundamente.

"Eu lembro do pai indo para o banheiro, ameaçando bastante a mãe. O meu irmão sempre se metia, desde pequeninho se metia nas brigas. Aí ele pegou a arma, foi para o banheiro e trancou a porta com a mãe lá dentro. A gente ficava tentando ouvir o que estava acontecendo. Meu irmão ficava tentando abrir e batendo na porta. E aí depois ele levou a mãe para o banheiro dos fundos e ficou trancado aí também. O tempo todo ele estava com a arma. [...] Éramos só nós dois em casa [ela e o irmão]. E aí depois veio a vizinha porque ouviu o barulho veio e tentou acalmar meu pai. Ela ouvia a briga na janela, ficava conversando, acalmando ele, pedindo para ele sair dali. Minha mãe estava bem nervosa, chorando." 
Quando conta o ocorrido, diz que não consegue entender o fato de não ter tido nenhuma reação depois de a mãe ter saído daquela situação: eu me lembro que o meu irmão abraçou a minha mãe com força e eu não conseguia fazer nada, fiquei parada. A passividade de Gerusa atualiza o impacto do trauma, não pode fazer nada com o excesso frente à desmesura do vivido. O único ato que pode fazer é contra si mesma.

Propõe-se, portanto, buscar compreender a referência ao tema do excesso. De que excesso fala sem palavras o ato de Gerusa? O excesso para ela é a ameaça real de desamparo. O nascimento do irmão ameaça sua sobrevivência psíquica. A mãe deixa-a junto com o irmão em casa para serem cuidados por um pai alcoolizado. O que está descuidado em Gerusa faz com que o traumático irrompa.

$\mathrm{Na}$ etiologia dessa modalidade de tentativa de suicídio, o tema edípico não se faz presente como na neurose no terreno da exclusão. Trata-se aqui de uma vivência edípica na qual tanto o pai como a mãe, ou ambos, não puderam colocar em um tempo anterior essa criança no lugar de "sua majestade o bebê". Freud (1915/2004) usa esta expressão para descrever o lugar ocupado pela criança na relação com os pais à medida que ela passa a ser depositária de tudo que estes desejaram ser: "a criança deve satisfazer os sonhos e os desejos nunca realizados dos pais, tornar-se um grande homem e herói no lugar do pai, ou desposar um príncipe, a título de indenização tardia da mãe" (p.110). Dessa forma, o amor parental manteria essa estreita ligação com o processo de renascimento do narcisismo dos pais frente ao nascimento de um filho.

Na história infantil de Gerusa, faltou-lhe ocupar esse lugar de ser o objeto de esperança dos ideais não realizados pelos pais. Gerusa não foi investida como um objeto de esperança para o qual se abre a noção de devir e de possibilidade de investimento em projetos de vida. As constantes restrições sofridas falam de um espaço familiar marcado pela desesperança. A fantasia de ser a morte do pai a única alternativa de salvação faz com que busque como saída este caminho de morte de desfazer vínculos com Eros. Um pai alcoolista, uma mãe submissa e frustrada com sua vida, mas presa nesta escolha que a deprime, um irmão que não pode ser nomeado em sua homossexualidade. Cabe à Gerusa confirmar, com suas tentativas de suicídio, com seus atos de tentar acabar com a própria vida, o predomínio e a vitória da desesperança. A desesperança aqui é proposta no sentido que lhe outorga Fischbein (1999). Para o autor, "a desesperança que aparece nesses momentos está dada pela claudicação do aparelho psíquico na realização de seus movimentos de reinvestidura. Os sujeitos se queixam de uma vaga sensação de vazio, de transtornos indizíveis e de sentirem-se imersos em um universo pleno de carências e com difusa excitação" (p.277). Para o autor, o traumático ataca o investimento narcisista e daí resulta a experiência de desvalimento. 
Gerusa é nomeada pela mãe durante a briga no hospital como uma consumista, alheia ao que poderia ocorrer com a família após a morte do pai. Gerusa não se reconhece nas palavras da mãe, mas também não sabe nomear-se. Sente-se "um nada” e, assim, usa a morfina do pai para silenciar sua dor. Sua tentativa tem conseqüências como a deformação de seu corpo. É como se ele passasse a espelhar o excesso que lhe acompanha dentro.

\footnotetext{
“Cheguei a ter uma parada cardiorrespiratória, mas não fiquei com nenhuma seqüela. Quando eu fui para a Psiquiatria do hospital e me olhei no espelho e fiquei muito assustada comigo. Isso que já não era o jeito que eu estava antes. Dizem que eu estava enorme, parecia uma mulher de cento e poucos quilos."
}

\section{O ATO-DOR E A ESCUTA ANALİTICA}

Neste texto, abordou-se a seqüência de excesso, dor e ato que está presente na tentativa de suicídio que tem como ponto de ancoragem as vivências traumáticas do sujeito. A partir do material apresentado, propõe-se nomear a tentativa de suicídio resultante de vivências traumáticas como sendo um ato-dor.

Entende-se como ato-dor um ato decorrente da vivência de situações traumáticas acrescidas da incapacidade psíquica de processar este excesso. No ato-dor observa-se o predomínio do ato como forma de evacuação dessas quantidades que provocam dor psíquica e deixam o sujeito encurralado num processo de repetição. Para compreender-se a ocorrência e dinâmica dessa modalidade de ato, é necessário recorrer aos conceitos de trauma, dor psíquica, compulsão à repetição e irrepresentabilidade.

O conceito de compulsão à repetição foi aqui entendido como força de impulsão do ato-dor, pois ele é, segundo Laplanche e Pontalis (2001), "ao nível da patologia, processo incoercível e de origem inconsciente, pelo qual o sujeito se coloca ativamente em situações penosas, repetindo assim experiências antigas sem se recordar do protótipo" (p.83). Dessa ausência de memória decorre a sensação de motivação atual e de novidade que acompanha a repetição. A dor resultará exatamente do circuito que evacua, mas não elabora o excesso.

Dor, compulsão à repetição e ato se confundem na busca de dar fim a algo que atormenta o sujeito. A desesperança é a companheira e motor de combustão para a busca de fim. O ato-dor está relacionado à incapacidade de atribuição de sentido a essa quantidade que ingressou no psiquismo. Tal modalidade de ato denuncia uma urgência subjetiva conforme descreve Seldes (2005). Ao usar a expressão "urgência subjetiva", o autor está se referindo à possibilidade de aplicar a psicanálise àquelas situações de urgência nas quais o sujeito não pode ainda sustentar uma demanda, ou seja, situações de desespero. Nesse caso, pode-se "oferecer-lhe uma assistência imediata que lhe dá a possibilidade de captar, com 
as variáveis que traz, aquilo que sumiu no desespero, o que o deixou perplexo, agoniado e inclusive desacorçoado" (p.24).

É necessário considerar que diversos autores da psicanálise (MARCELLI \& BRACONNIER, 1989; KNOBLOCH, 1998; FLECHNER, 2000) salientam que a tentativa de suicídio deve ser sempre entendida como indício de uma perturbação importante nos arranjos pulsionais e recursos defensivos. Especificamente, Marcelli e Braconnier (1989) evidenciam que "embora efetivamente haja urgência de escutar o suicida, nem sempre há urgência de agir, de 'fazer alguma coisa'. Em matéria de tentativa de suicídio, a única urgência é a urgência da escuta” (p.112). A necessidade de escutar e de buscar formas de construir um recurso a fim de processar psiquicamente o que provoca dor psíquica apóia-se na proposição de que, na tentativa de suicídio, o sujeito está frente à força do traumático. Knobloch (1998) descreve como sendo da ordem do traumático "aquilo que rompe com os sistemas de representação, ou seja, o irrepresentável” (p.22). Segundo Flechner (2000), "parece fundamental esclarecer que a tentativa de suicídio ou o suicídio se converterá em um momento no qual uma quebra entre pensamento e ato deverá fazer-se presente" (p.57).

Por meio de um exemplo relativo a pacientes com impulsos suicidas, Ferenczi (1932/1997) descreveu o modo como um terapeuta pode convocar o paciente a falar sobre a situação traumática, mas, agora, em outro contexto. Para o autor, é favorável mostrar ao paciente que ele não está inteiramente só. Afirma Ferenczi (1933b/19927) que

\footnotetext{
“talvez não lhe possamos oferecer tudo o que caberia em sua infância, mas só o fato de que possamos vir em sua ajuda já proporciona o impulso para uma nova vida, na qual se fecha o dossiê de tudo o que se perdeu sem retorno e, além disso, efetuando o primeiro passo, é permitido contentar-se com o que a vida oferece, apesar de tudo. Não rejeitar em bloco, mas vitalizar o que ainda pode ser utilizável.” (p.117)
}

A capacidade de construir um escudo protetor a partir do complexo representacional que servirá como um recurso importante para o sujeito processar os estímulos externos depende, segundo Fischbein (1999), "da sedimentação das experiências de vida de cada sujeito e da ajuda que teve de seus objetos primários para processá-las" (p.275). A respeito da possibilidade de elaboração das experiências traumáticas, Maia (2003) considera que "é preciso fazer surgir no setting afetos que, por sua dimensão traumática, provocam cisões patológicas para o sujeito. Entendo que o sujeito que tem sua vida psíquica em parte devassada por aspectos traumáticos age a dor, sendo incapaz de significá-la” (p.238). Nesse sentido, para a autora, muitas vezes, no espaço transferencial, a compulsão à repetição se apresentará como "uma oportunidade, às vezes única, de fazer mover 
essa engrenagem tão delicada que se monta a partir das vivências traumáticas patológicas” (p.239). Ao marcar a diferença entre agir a dor e expressar a dor, a autora considera que a repetição dos afetos nesse espaço possibilita a retirada das experiências traumáticas da clandestinidade e do estado de dissociação.

A escuta analítica é fator essencial quando o ato ocupa o lugar das palavras. Escutar o ato-dor é escutar o irrepresentável, ou seja, é a escuta do que escapa ao complexo representacional do sujeito. A repetição será trabalhada e nomeada no terreno da transferência e assim poder-se-á construir, junto com o paciente, palavras que metabolizem o excesso. Na mesma linha de pensamento adotada neste artigo, Fischbein (1999) assinala que nesses casos "não se trata do desvelamento de uma história recalcada, mas de inscrição e de armar o texto do que não foi representado" (p.280). Somente o trabalho com uma história significante poderá conter um ato. Assim, o espaço de escuta pode ser um fator vital na vida desse sujeito aprisionado pela repetição. Para Maia (2003), a possibilidade de recuperação da experiência traumática em um processo de análise "poderá conferir um lugar psíquico aos afetos e às marcas traumáticas que, por sua característica patogênica, se reproduzem ad infinitum, obliterando a possibilidade de devir subjetivo" (p.174). As sensações envolvidas na clivagem não deixam lugar "a uma emoção propriamente dita" (FISCHBEIN, 1999, p.277). Assim, ao tirar essa experiência do estado de dissociação, devolve-se ao sujeito a capacidade de apropriar-se de si mesmo, de transformar dor em sentimento. Ao romper a cisão que o incapacita a ser dono de seu destino, abre-se à palavra um recurso de mediação do mundo psíquico.

Gerusa, após ser escutada, conta:

"Eu me senti mais leve, também acho que vir aqui me fez pensar nas coisas. Eu inclusive dormi melhor sem remédio, que é uma coisa que eu não estava conseguindo. No hospital eu estava tomando um remédio até para poder dormir. Em casa eu não estava conseguindo dormir, faltava o remédio. [...] Eu acordo até antes do relógio, que era uma coisa que eu não ouvia o celular tocando no volume máximo. De manhã, nos últimos dias [...] eu não estava conseguindo acordar."

A tentativa de suicídio de Gerusa pode ser entendida como um ato-dor que traz condensado em si uma história de excessos. Excesso de faltas que a vão deixando à mercê da impossibilidade de atribuir uma representação simbólica a suas vivências. Neste cenário de desesperança, Gerusa vai tecendo os fios de um entramado que não altera suas repetições. A desmesura do que a invade condena-a a não ter esperança. Investir em um tempo futuro exige um montante de energia que evidencia sua carência. Gerusa expressa não poder afirmar que não voltará a tentar se matar, pois já o fez duas vezes. Ao mesmo tempo, esboça uma esperança nesse espaço de escuta, ao falar de seu entusiasmo com 
o início de um processo terapêutico para o qual foi encaminhada. Acredita-se que a relação analítica viabilize o acesso de Gerusa a um território vitalizado e de esperança para que ela possa, então, interromper um conhecido circuito de trauma, dor e ato.

Recebido em 18/6/2006. Aprovado em 23/10/2006.

\section{REFERÊNCIAS}

BERLINCK, M. T. (2000) Psicopatologia fundamental. São Paulo: Escuta.

BOTEGA, N.J. \& WERLANG, B. (2004) "Avaliação e manejo do paciente”, in WERLANG, B. \& BOTEGA, N.J. (org.). Comportamento suicida. Porto Alegre: Artmed.

FERENCZI, S. (1933a/1992) “Confusão de línguas entre os adultos e as crianças”, in Obras completas de Sándor Ferenczi. São Paulo: Martins Fontes.

(1933b/1992) "Reflexões sobre o trauma”, in Obras completas de Sándor Ferenczi. São Paulo: Martins Fontes.

FIGUEIREDO, L. C. (2003) Psicanálise: elementos para a clínica contemporânea. São Paulo: Escuta.

FISCHBEIN, J. E. (1999) Más allá de la representación: el acto. Revista de Psicoanálisis de la Asociación Psicoanalitica Argentina, v.6, n. 2. Buenos Aires: APA, p.261-280.

FLECHNER, S. (2000) Acerca de los intentos de autoeliminacioón y suicidios en la adolescencia. Publicación Primero Congresso de Psicoanálisis y $11^{\text {as }}$ Jornadas científicas de la Asociación Psicoanalítica del Uruguay. Tomo II, p.53-65.

FREUD, S. (1987) Edição standard brasileira das obras psicológicas completas de Sigmund Freud. Rio de Janeiro: Imago.

(1892) “Esboços para a comunicação preliminar de 1893”, v. 1, p. $165-174$.

(1895) “Projeto para uma psicologia científica”, v. 12, p.381-409.

(1905) “Tratamento psíquico ou mental”, v. 7, p.297-316.

(1920/1976)) “Além do princípio do prazer”, v. 17, p.17-85.

(1922/1976) “Alguns mecanismos neuróticos no ciúme, na paranóia e no homossexualismo”, v. 17, p.271-281.

(1914/2004) “À guisa de introdução ao narcisismo”, in Escritos sobre a psicologia do inconsciente. Rio de Janeiro: Imago.

GEREZ-AMBERTIN, M. (2003) "Entre el pasage al acto e acting out". Pulsional Revista de Psicanálise, 16/169. São Paulo: Escuta, p.9-17.

HORNSTEIN, L. (1989) Introdução à psicanálise. São Paulo: Escuta.

KNOBLOCH, F. (1998) O tempo do traumático. São Paulo: Educ.

LAPLANCHE, J. \& PONTALIS, J.-B. (2001) Vocabulário da psicanálise. São Paulo: Martins Fontes. 
MAIA, M. S. (2003) Extremos da alma. Rio de Janeiro: Garamond.

MARCELLI, D. \& BRACONNIER, A. (1989) Manual de psicopatologia do adolescente. Porto Alegre: Artes Médicas.

SELDES, R. (2005) “La urgencia subjetiva”. Revista Psicolibro. Buenos Aires: Paidós, p. 24.

VALLS, J. L. (2004) Metapsicologia y modernidad: el Proyecto freudiano. Buenos Aires: Lugar Editorial.

Mônica Medeiros Kother Macedo

monicakm@pucrs.br

Blanca Susana Guevara Werlang

bwerlang@pucrs.br 